\title{
Studies on Tracheary Element of Several Native Cycad Species in Australia and Two American Plants
}

\author{
Yuyuan Huang1,2*, Harvey Ottley ${ }^{3,4}$, Yolande Yep ${ }^{5,6}$, Sharon Wilson3 ${ }^{3}$, David Griffiths ${ }^{3}$, \\ Nikeeta O'sullivan' ${ }^{5,6}$, Yanhua Han', Jane Hempel ${ }^{3}$ \\ ${ }^{1}$ College of Life Sciences, Zhongkai University of Agriculture and Engineering, Guangzhou, China \\ ${ }^{2}$ Agricultural College, Guangxi University, Nanning, China \\ ${ }^{3}$ George Brown Darwin Botanic Gardens, Darwin, Australia \\ ${ }^{4}$ Palm and Cycad Society of the Northern Territory, Darwin, Australia \\ ${ }^{5}$ School of Environment, Charles Darwin University, Darwin, Australia \\ ${ }^{6}$ Research Institute for Environment \& Livelihoods, Charles Darwin University, Darwin, Australia \\ Email: ^huangyy233@126.com
}

How to cite this paper: Huang, Y.Y., Ottley, H., Yep, Y., Wilson, S., Griffiths, D., O'sullivan, N., Han, Y.H. and Hempel, J. (2022) Studies on Tracheary Element of Several Native Cycad Species in Australia and Two American Plants. American Journal of Plant Sciences, 13, 147-174. https://doi.org/10.4236/ajps.2022.131010

Received: December 8, 2021

Accepted: January 25, 2022

Published: January 28, 2022

Copyright $\odot 2022$ by author(s) and Scientific Research Publishing Inc. This work is licensed under the Creative Commons Attribution International License (CC BY 4.0).

http://creativecommons.org/licenses/by/4.0/

\begin{abstract}
Cycas angulata, Cycas armstrongii and Cycas conferta that are native species of Australia were collected in Darwin city of tropical region, Zamia erosa and angiosperm Guaiacum officinale of Zygophyllaceae which are introduced collected in the Darwin Botanic Gardens, and were carried out light microscope and electron microscope observed research to tracheary element and parenchyma tissue cells of leaflet, rachis and stem. The results showed that there are more vessel elements in their xylems; the length of vessel element of Cycadaceae with Zamiaceae are not obvious difference, the length of vessel element of angiosperm Guaiacum officinale is shorter, but their diameter is smaller, we thought that the characteristics which the length of vessel element is longer and the diameter is bigger are more evolutionary, because thus vessel, their number which interconnected points of possessed perforations' end walls of vessel element is fewer, and the passageway space is larger so that the conduction speed and quantity are faster and more in unit length range and unit time. These vessels are annular vessels, spiral vessels, scalariform vessels, reticular vessels, pitted vessels and scalariform-pitted vessels, etc. In the transverse section, the vessel elements of Cycadaceae and Zamiaceae are circular, polygonous, more similar to vessel characteristics of leaf and stem of some angiosperms; however, the number of circular vessel of Guaiacum officinale is more, about occupy $35 \%$, others are polygonous. The diameter of vessel is that annular vessel, spiral vessel is least, scalariform vessel or scalariform-reticular vessel is medium, reticular vessel and pitted vessel are the big-
\end{abstract}


gest, the characteristic is same as angiosperm. In Cycas conferta, etc. plants often can see several large perforations in the end walls, some species are several big scalariform or pitted perforations formed multiple perforation plates, in many vessel element lateral walls, there are some perforations formed a horizontal transport avenue of aqueous solution. The scale of diameter of Cycas vessel element is similar to that of Zamia, but the diameter of more vessel elements of Cycas angulata and Cycas conferta is bigger than the latter, and is bigger than that of Guaiacum officinale, although Cycas plants are more primitive than Zamia plants, and Guaiacum officinale is more evolutionary, but the scale of vessel diameter of Cycas plants is similar to Zamia or bigger than the latter, even larger than Guaiacum officinale, these showed that cycads have evolutionary and more developed characteristics in aqueous solution transport system. In Guaiacum officinale, more vessel element has been not seen the ridges in the different directions of side walls which can make vessel has more mechanical supportability, but some possessed the ridges; however, more vessel elements are twist shape and can twist together each other, thus the state can increase their mechanical supportability, and their synergy with fiber elements which is longer with a twist shape, therefore their capability of xylem conduction and the combine mechanical support capability with mechanical tissue are also stronger. In the respect of observed parenchyma tissue, any parenchyma tissue cells are without perforation, all cell walls are smoothed and like a membrane. Aimed at only one or two people pointed the query about Jeffery's method, some scholars have made comparative researches, their research used as following methods: 1) The fresh materials were cut sections $1-2 \mathrm{~mm}$ thick by hand (the query person provided and thought right method), were examined with SEM. 2) The materials were treated by Jeffrey's Fluid and observed with SEM and so on. The results showed that the pit membrane, the remnants in the perforation and the structural characteristics of perforations were not different; and the results of our comparative research in past time and this research all justified that Jeffrey's method is reliable and reasonable. Meanwhile, our research results showed that only vessel element can form perforation, in other all parenchyma tissue cells cannot form perforation are also proved that the perforations of vessel element are naturally inherited character. Analyzed from the structural characteristics, although they distributed so far apart from each other, they are a well and unified taxonomy system; we thought that Australia' most species or all species of Cycadaceae came from Asia, and it is impossible from Africa, because the latter only has one more evolutionary species and lack of fossil of Cycadaceae, these species of Cycadaceae are the descendants of ancestor species; America possessed more genera of Zamiaceae, this family is mutual with Africa and Australia, we thought that these genera of Zamiaceae in Australia and America came from Pangea before continental drift in Jurassic Period, this family is also maybe one of the proofs to Australia drifted from Pangea to present position after Jurassic Period. The characteristics of tracheary element of several different genera of cycads and angiosperm further showed that more primary species or taxon, their more tissue 
characteristics are not also more primary, because of the need to adapt the environment, they are also constantly evolving. The research is important significant and theory reference to understand cycads evolutionary aqueous solution transport system, and understand the ecological adaptation mechanism which why present cycads of 3 families in world major distributed in tropical or subtropical regions, even many drought and barren areas.

\section{Keywords}

Cycad, Evolution, Vessel, Native Species, Structural Characteristics

\section{Introduction}

Cycads are very primitive seed plants of ancient; they originated from about the Carboniferous period [1], and still possess primitive characteristics in external morphology and internal structure, such as sperm with flagella. Metasequoia glyptostroboides $\mathrm{Hu}$ et Cheng is an ancient, rare "living fossil". Research on more species of cycad structural characteristics of tracheary elements is important to understand their adapted mechanism and evolutional extent. Such research can also promote effective measures to cultivate, breed and create the right conditions for increasing their individual population in the natural community. In 1999, Huang and Zhang published a brief report on the first discovery of vessels in Zamia furfuracea of cycads [2]. Lin \& Huang published another brief report on vessel features in the root of Cycas elonga [3], and another brief report on discovered vessel in the plant of Stangeriaceae [4], Huang and Liao [5] published a brief report on discovered vessel in Coniferae and Taxinae, and Huang and $\mathrm{Wu}$ [6] discovered vessels in Cycas panzhihuaensis. Huang et al. [7] reported the structural feature of vessels on four genera of cycads and some angiosperms; Huang et al. [8] published the structural characteristics of vessels in three families of Cycadopsida, Huang et al. reported the structural characteristics of vessels of some gymnosperms and angiosperms [9].

The present report is a comparative study on structural features of the xylem of these native cycads of Australia and America a cycad species and angiosperm, in an attempt further research and understanding their characteristics to more species of different regions...

\section{Materials and Methods}

The pinna and rachis of Cycas angulata, Cycas armstrongii and Cycas conferta which are Australia native species, pinna and rachis of Zamia erosa and leaf and stem of Guaiacum officinale which are introduced from America were collected from living trees in the George Brown Darwin Botanic Gardens, All materials were random sampling, therefore ensure whether these different plant taxon maybe almost all plants are having the characteristics under the condition of random sampling. After collection, these materials were cut into $1 \times 1 \mathrm{~cm}$ pieces 
and fixed immediately in FAA (formalin: acetic acid: glacial ethanol 70\%, 5:5:90), then macerated and dissociated by $10 \%$ nitric acid $+10 \%$ chromate solution, volume proportion 1: 1 (strict control dissociated situation, only then tissue disentwine was stoped at once) [10] [11], and rinsed with water (Jeffrey's method). Some dissociated and section materials were observed and made photography using light microscope; other materials were and were dehydrated in a graded series that $100 \%$ ethanol and isogamy acetate were according with the proportion of 1.0:0 $\rightarrow$ 0.3:0.7 $\rightarrow$ 0.5:0.5 $\rightarrow$ 0.3:0.7 $\rightarrow 0: 1.0$ and, critical point-dried in $\mathrm{CO}_{2}$, then sputter-coated with gold for observation and photography by XL-30 ESEM and JEM-1200Ex/s scanning electron microscope (SEM).

\section{Results}

In the leaf, stem tissues of plants of Cycas angulata, Cycas armstrongii, Cycas conferta of Cycadaceae, Zamia erosa of Zamiaceae and Guaiacum officinale of angiosperm, their tracheary elements have perforations in end wall and lateral wall, numerous types of vessel elements were found. The structural constitution of tracheary element in gymnosperms of two families is the same or basic same as this family of angiosperm, but every species has itself feature in detail morphology character. The structural characteristics of these vessels are described next.

\subsection{Cycas angulata}

There are scalariform vessels, reticular vessels, pitted vessels and scalariform-pitted vessels in the pinna, rachis, the mesh of some reticular vessel elements is irregular (Figure 1(1)), In these vessel elements, perforations are found in the lateral wall, while that of a portion of these elements, near pitted vessels, some reticular vessels, their septa or bars of ornamentation consist of secondary wall shape a lightly sloping arrangement, some have several ridges on the outside of the vessel element (Figure 1(1), Figure 1(2)), there are more scalariform and reticular perforantions, while there are more near oval or circular perforations in side walls of pitted vessels. In some scalariform vessels, a side is scalariform, and another side is pitted perforations (Figure 1(1)).

Some scalariform-reticular vessels are bigger, the diameter are about $32 \mu \mathrm{m}$, some pitted vessels diameter reached about $50-56 \mu \mathrm{m}$, in their lateral walls have many perforations (Figure 1(3), Figure 1(4)); through these perforations, that the ornamentation and perforations on the interior wall of the vessels can be seen (Figure 1(1), Figure 1(3)).

Many perforations of scalariform vessels are so large to $16 \mu \mathrm{m}$ long, $5.2-7.2$ $\mu \mathrm{m}$ wide, in the pitted vessels, many perforations arranged a line, the diameter is about $4-6 \mu \mathrm{m}$, some perforations near oval with 6.8 - $7.2 \mu \mathrm{m}$ length and 6.3 width. Some reticulate vessel elements, their diameter reached about $67-70 \mu \mathrm{m}$, more perforations with $10-13 \mu \mathrm{m}$ length, and $3.7-4.8 \mu \mathrm{m}$ width in the side wall (Figure 2(1)).

In the xylon, there are many fiber elements, they are twisted shape and with a 


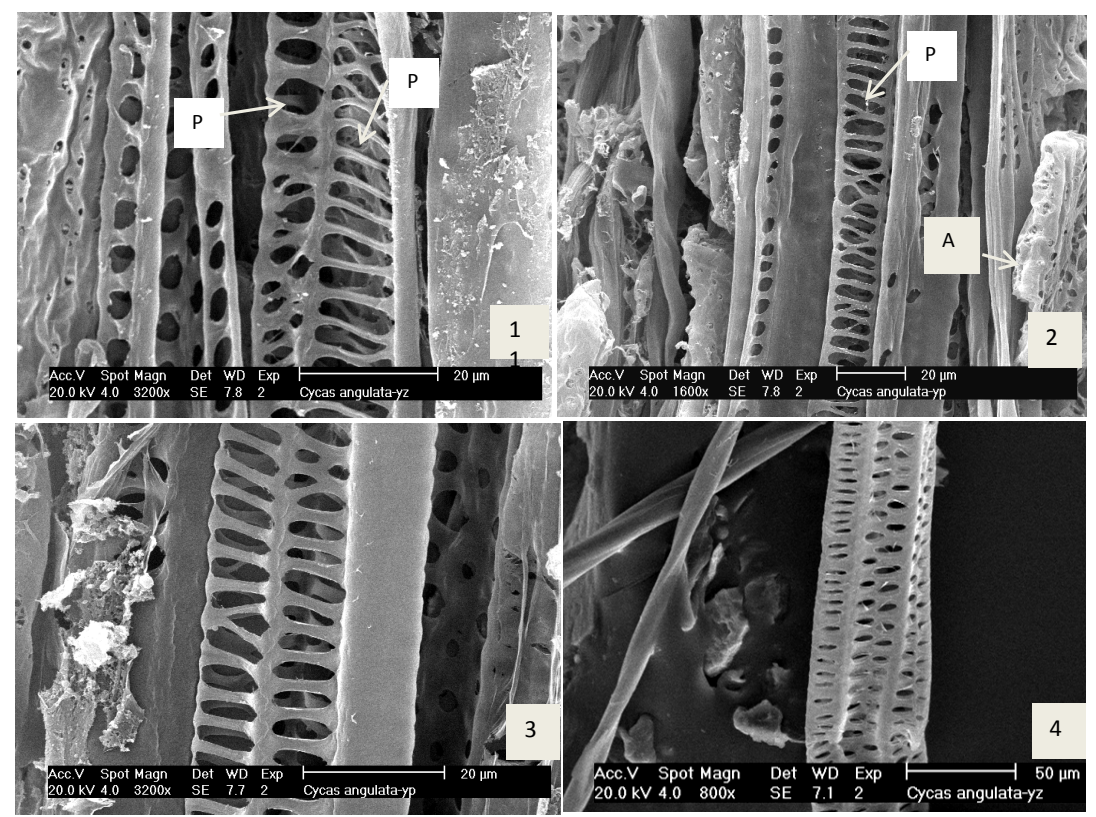

Figure 1. (1) A reticular vessel, it is bigger, and two pitted vessels in pinna (P: perforation). (2) Several reticular vessels, their end wall and lateral walls have more perforations, pinna (P: perforation, A: accessory transfusion tissue cell); (3) Some scalariform-reticular vessels, there are several lines perforations in their side wall, pinna. (4) A vessel element of scalariform-pitted vessel, the pits are intercolumn arrangement, they showed that a face of side wall was scalariform perforations, and another face of side wall was pitted perforations.
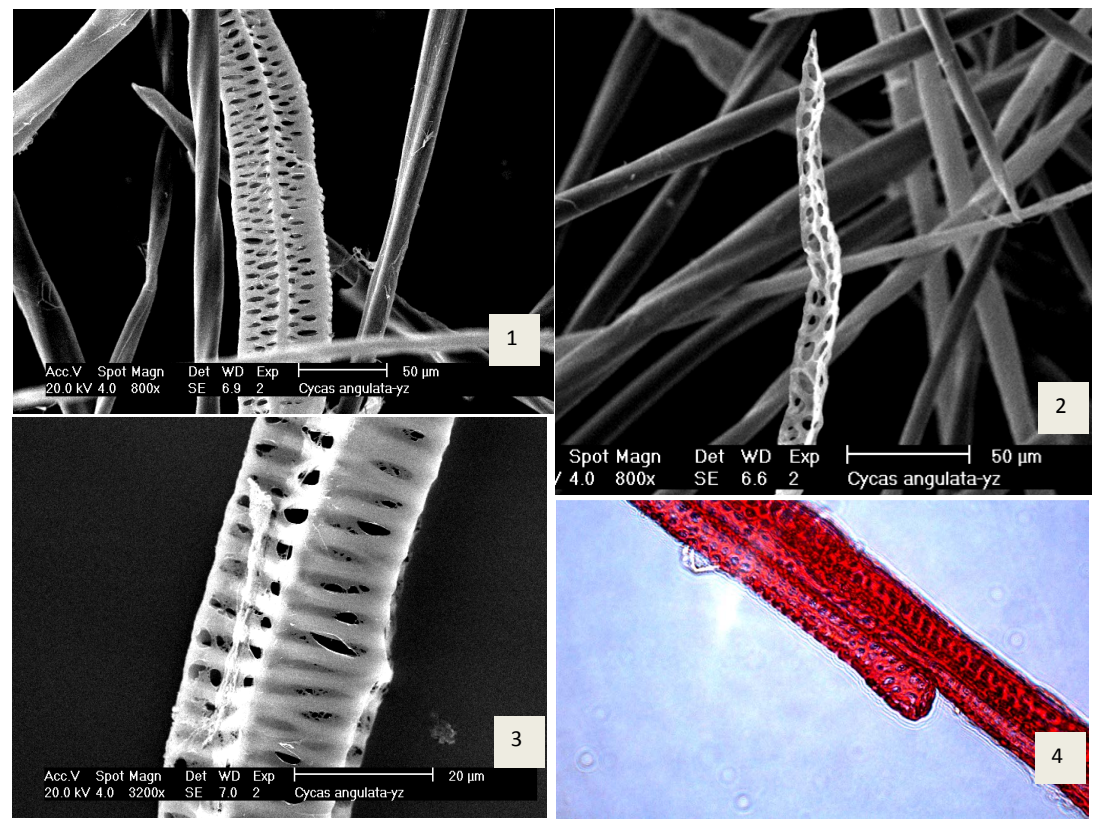

Figure 2. (1) A reticulate vessel element, more perforations in the side wall. (2) A pitted vessel element, the end wall was very incline, there was some preforations in end wall and some perforations in the lateral wall and some fibre elements which are twisted shape and are tip in the end. (3) A scalarifum-reticulate vessel element, some sections of the lateral walls have perforations, while others do not, in addition, on the outside of some pits, a pit membrane can still be seen. (4) Some pitted-reticular vessel, many perforations in the side wall, it has a near horizontal end wall with several perforations. 
tip in the end, some pitted vessels diameter is less, and are only $10-12 \mu \mathrm{m}$, about 12 - 15 perforations distributed in the inclined multiple perforation plate of end wall (Figure 2(2)).

In pinna, a reticular vessel, some reticular and near circular perforations in side wall, these perforations are 12 - $15 \mu \mathrm{m}$ length, and $4-6 \mu \mathrm{m}$ width. The pitted vessels, the diameter are about $30-32 \mu \mathrm{m}$, in a side wall, some circular perforations arranged a line, in other sides, there still are primary wall or more primary walls in the outside of vessel elements, and can see inside secondary wall ornamentation (Figure 1(2); Figure 2(3)). In pinna and rechis, the round vessels of Xylem of conduction tissue, there are some accessory transfusion tissue cells, they are near short rectangle shape, the side walls and the horizontal or near horizontal end walls have more pitted or pitted-rectangular perforations (Figure 1(1), Figure 1(2)); the action of these are bearing the synergy to conduct aqueous solution with vessels of xylem in longitudinal and transverse directions, but the their synergy action main is transverse conduction, they connect other tissues, so that some aqueous solution easier entry these tissues, or opposite direction conduct some nutritive materials entry the vessels.

In the xylem, fibre elements is tip and twist-shaped (Figure 2(1), Figure $2(2))$; in some scalarifum vessel elements, some sections of the lateral walls have perforations, while others do not. In addition, on the outside of some pits, a pit membrane can still be seen; the few pit membranes that remained on the surface of perforations are threadlike, sheet-like, shred-like, and mesh-like in shape (Figure 2(3)).

In some vessel element of scalariform-pitted vessel, the pits are intercolumn arrangement, some scalariform and pitted perforations in the lateral walls. They showed that a face of side wall is scalariform perforations, and another face of side wall is pitted perforations (Figure 1(4)). In some scalariform-pitted vessels, their end walls of vessel element are near horizontal shape, showed very evolutary characteristics (Figure 2(4)).

\subsection{Cycas armstrongii}

Some spiral vessels, scalariform vessels, pitted vessels and scalariform-reticular vessels are distributed in pinna and rachis. Multiple perforation plates were found in the end walls.

In some scalariform vessels, the septa or bars of ornamentation consist of secondary wall are longer, and more longer perforations in the side walls, the perforations length can reached 25 - $28 \mu \mathrm{m}$ with width 6 - $7 \mu \mathrm{m}$ (Figure 3(1)).

Some pitted vessels possessed a more acuate tip with very inclined perforation plate in the end wall with some perforations, the lateral walls of these pitted vessels have many perforations, in some scalariform vessel elements, their lateral wall possessed many perforations, in end wall, the extent of inclination is large, so that the end wall is rather difficult to distinguish from the lateral wall (Figure $3(2))$. 


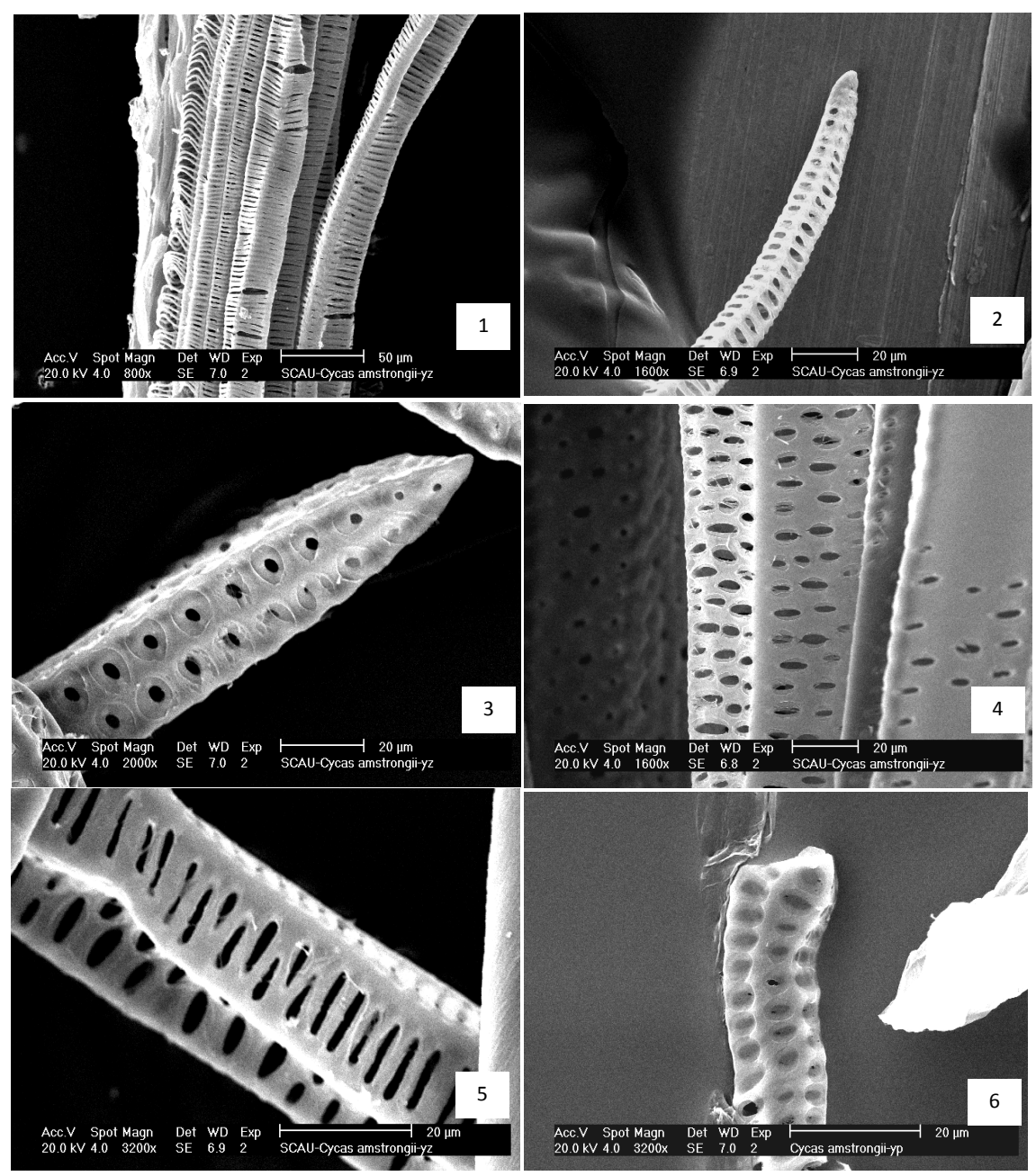

Figure 3. (1) Rachis, Some bigger scalariform vessels, their side wall have more perforeations. (2) A scalariform vessel elements, its side walls in several sections have more perforations, rachis; (3) A bordered pit vessel elements, their pits are interlaced arrangement; its side walls have more perforations, rachis; (4) Several pitted vessel elements, more perforations in their lateral walls, rachis; the pits are also interlaced arrangement; (5) A scalariform-reticular vessel element, there are more perforations in the lateral walls; (6) A vessel element, it possess near horizontal end walls, and its lateral walls have several perforations.

Some bordered pit vessel elements that their pits are interlaced arrangement, the diameter of vessels are $30-37 \mu \mathrm{m}$ in the lateral wall possessed more perforations. Some perforations are 7 - 8 length, with $4.7-6 \mu \mathrm{m}$ width (Figure 3(3), Figure 3(4)).

The diameter of some scalariform-reticular vessel elements are about $25.2 \mu \mathrm{m}$, its side wall is more scalariform, and another side is scalariform-reticular shape, in the lateral wall, there have more perforations, the length of the perforation is $17-23 \mu \mathrm{m}$, and the width is $6-8 \mu \mathrm{m}$ (Figure 3(5)). Some pitted vessels possessed near horizontal or horizontal end walls, in the side wall, few pits have formed perforations; more pits still have pit membrane in periphery (Figure $3(6))$. 
Some spiral vessels are smaler, their side walls have more perforations (Figure $4(1)$ ), pitted vessels possess a more acuate tip with very inclined perforation plate in the end wall with some perforations (Figure 3(3)); in some pitted vessel elements, they are twisted shape, its lateral wall possessed many perforations, the extent of inclination is large so that the end wall is rather difficult to distinguish from the lateral wall, the lateral walls of these pitted vessels have many perforations (Figure 4(2)).

\subsection{Cycas conferta}

In pinna and rachis, which contained spiral, scalariform, reticular, and reticular-pitted vessels, all vessel elements have more perforations in their end walls and lateral walls.

Some scalariform vessel elements are longer, and their side wall has more large perforations, the diameter is $34-37 \mu \mathrm{m}$, some pitted vessels are bigger, the diameter are $42-47 \mu \mathrm{m}$ (Figure 5(1), Figure 5(3)), in some vessel elements, some sections of the lateral walls have perforations, while others do not, on the outside of some pits, a pit membrane there are some web, silk, filiform, little shred-like membrane remnants in the perforation surface can still be seen (Figure 5(1)).

In rachis, some spiral vessels near circular shape, in the lateral wall have two ridges which is consist of secondary wall, their side walls have many perforations (Figure 5(2)). In vessel elements side, some parenchyma tissue cells, they all are without any perforation in their any walls (Figure 5(2), Figure 5(3)). Some scalariform vessels, in the lateral wall have two ridges which is consist of secondary wall, curved strip partitions connected the redges, this should is the characteristics that from spiral vessel or annular vessel evolved to scalariform vessel (Figure $5(2))$. In rachis, some pitted vessels with twist-shaped, the lateral wall have more perforations (Figure 5(4)).

Rachis, in reticulate-pitted vessel element, some end wall has a tip, and with two bigger perforations, one of them' perforation is $46 \mu \mathrm{m}$ length and about 25

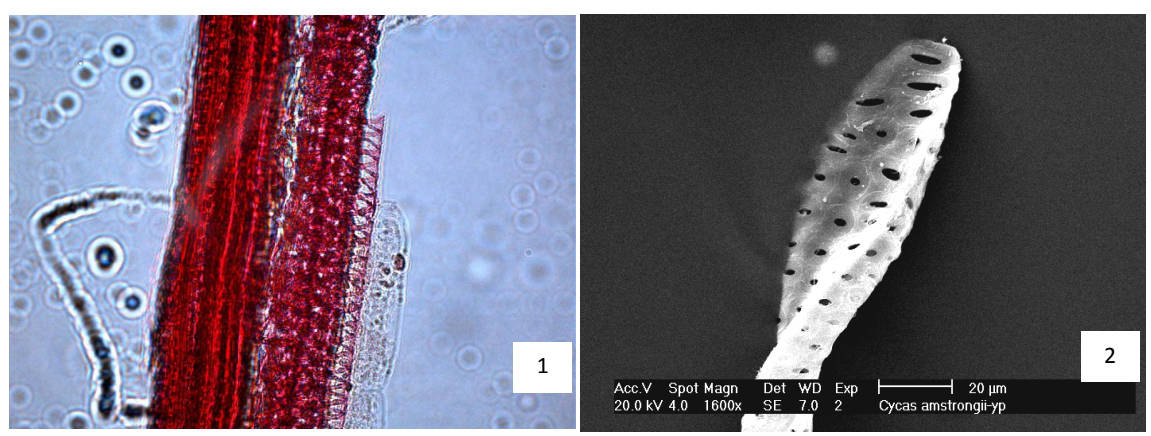

Figure 4. (1) Serveral spiral vessels, caraliform and pitted vessels, their side wall possessed some perforations, (Under light microscope, light come from in bottom of sample, so the sites of perforations are a lot of light passed through, therefore there are obvious bright), pinna. (2) A little scalariform vessel element, its lateral wall and end wall possessed many perforations; it is a twisted shape, rachis. 


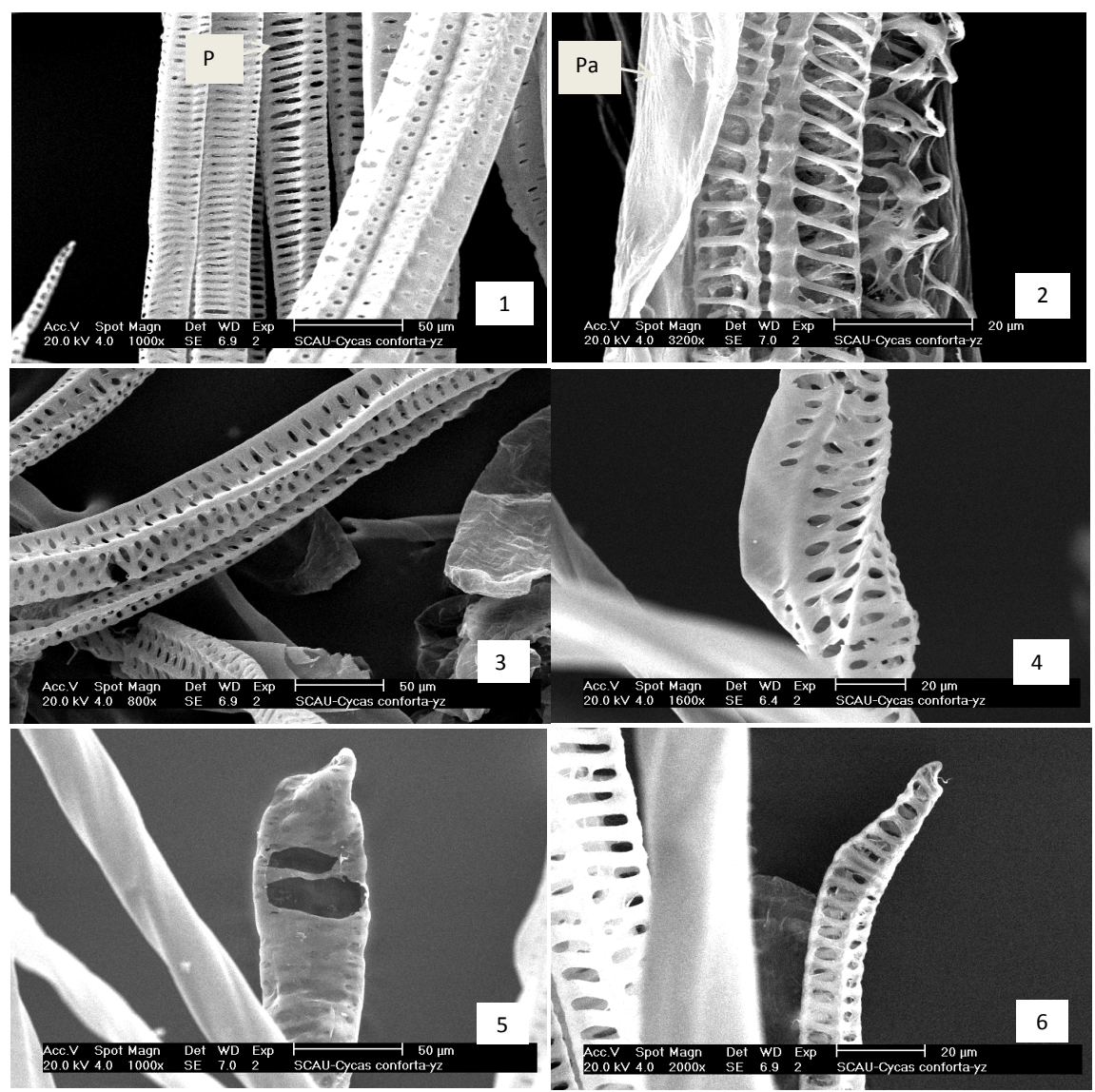

Figure 5. (1) Some scalariform and pitted vessel elements, rachis; (P: perforation); (2) Some scalariform vessels near circular shape, in the lateral wall have two ridges which is consist of secondary wall, their lateral wall possessed more perforations; some parenchyma tissue cells, they all are without any perforation in their any walls rachis; (Pa: parenchyma tissue cells); (3) Some pitted vessel elements, their lateral wall have more perforations, some parenchyma tissue cells, they all are also without any perforation in their any walls, rachis; (4) A pitted vessel element, it is a twisted shape, its lateral wall possessed some perforations, its pits are interlaced arrangement, rachis; (5) A reticulate-pitted vessel element, the end wall has a tip, and with two bigger perforations, rachis; (6) Some scalariform vessels possess very inclined perforation plate in the end wall, rachis.

$\mu \mathrm{m}$ width (Figure 5(5)). Some scalariform vessels possess very inclined perforation plate in the end wall with $17-20$ perforations per plate (Figure 5(6)).

In pinna, some pitted-reticular, pitted and scalariform-pitted vessel elements, their end walls are near horizontal, and the side walls possessed more perforations, some perforations with some silk, filiform, threadlike, shred-like membrane remnants in the perforation surface (Figures 6(1)-(3)), these showed that complete perforations are the characteristics of plant individual development, from the perforations of immature with some membrane remnants, developed to mature perforations which are without any membrane remnants [12].

Some pitted vessels have several pitted perforations in their several side of like tip end wall (Figure 6(4)). Many scalariform vessels possessed near horizontal or horizontal end walls and $4-5$ perforations in the perforation plate (Figure 6(2), 


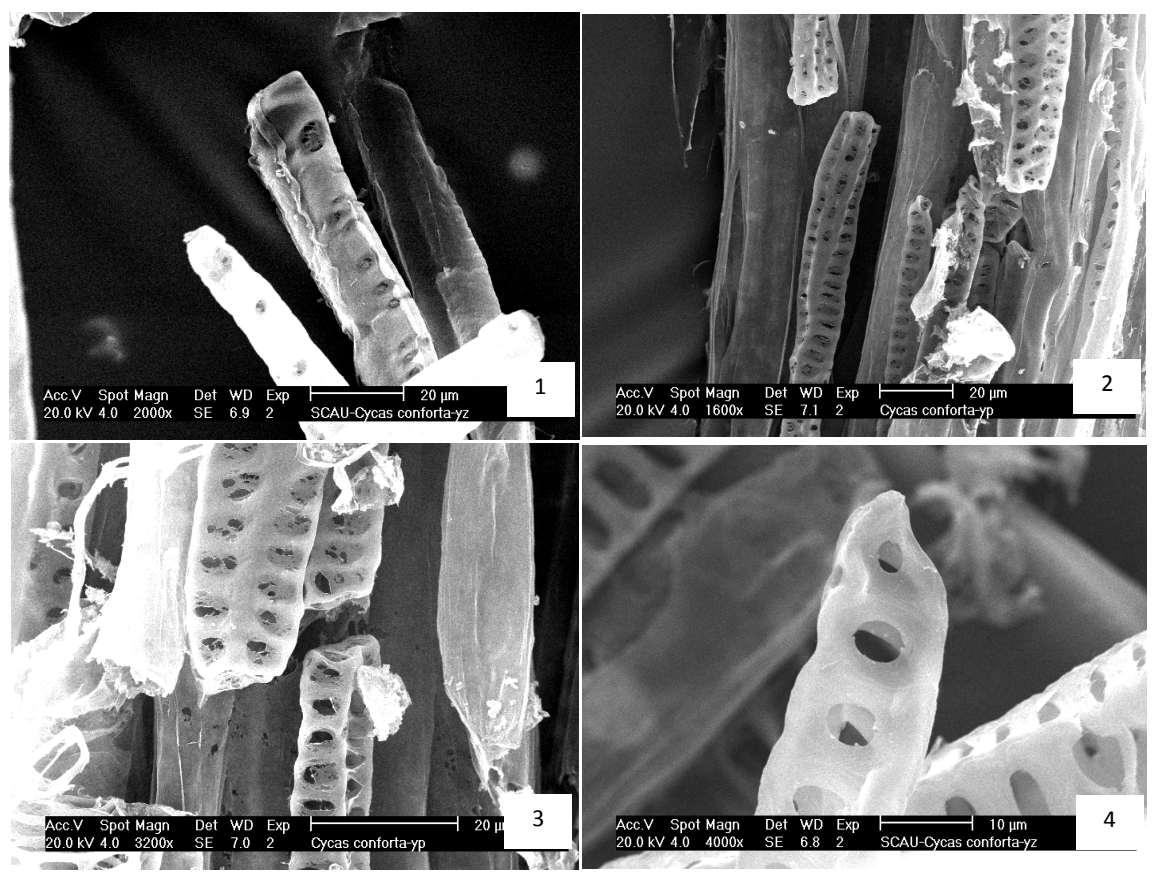

Figure 6. (1) Several pitted-reticular vessel and the side wall has some little perforations with some silk, shred-like membrane remnants in the perforation surface, the end wall near horizontal shape, rachis; (2) Some pitted and scalariform-pitted vessel elements, their end walls are near horizontal, and the side walls possessed more perforations, some perforations with some web, silk, little shred-like membrane remnants in the perforation surface, pinna; (3) Several pitted vessel elements, their several side walls have more perforations, some little perforations with threadlike, sheet-like, shred-like, mesh-like or band-like in shape membrane remnants in the surface, their end walls near horizotal shape, pinna; (4) Several pitted vessel elements, some perforation in the incline end wall, rachis.

Figure 6(3)). Two adjacent end walls that connect each other are also near horizontal status, in some vessels, the few pit membranes of web, little shred-likere shape mained on the surface of perforations (Figure 6(2), Figure 6(3)).

\subsection{Zamia erosa}

In the rachis, the scalariform vessel elements have many scalariform perforations in the lateral wall (Figure 7(1)), some pitted vessels is a twist-shape, their lateral walls have more perforations (Figure 7(2)), all parenchyma tissue cells have only a primary wall, wherefore preserve their integrity of wall of thin membrane shape and are without any perforation in their walls (Figure 7(4), Figure 7(5)). Some scalariform vessel elements possessed a long and inclined end wall, there are more perforations formed multiple perforation plate (Figure $7(3)$ ). Some firbs are thing and tip in the end wall; they are a few twist-shape (Figure $7(2)$, Figure 7(5)).

Some scalariform and pitted vessel elements are larger, their diameter reached $32-35 \mu \mathrm{m}$, and more perforations were distributed in the side walls (Figure 7(6)).

All parenchyma tissue cells are without any perforation in their walls, these 


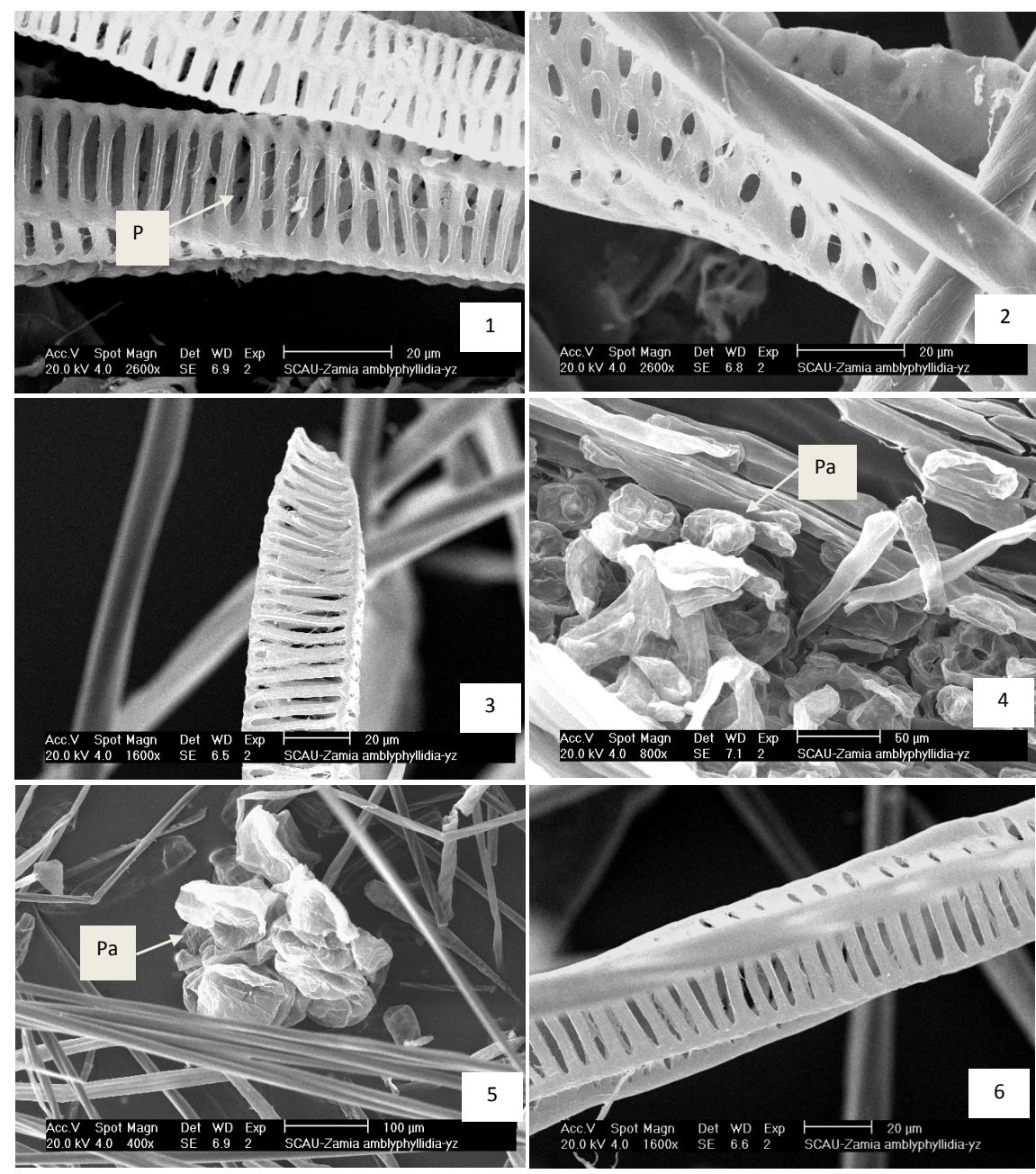

Figure 7. (1) Rachis, several scalariform vessel elements, in the lateral walls have many perforations surface, some perforations with some silk, filiform, shred-like membrane remnants; (P: perforation); (2) Several pitted vessels, their lateral walls have more perforations, rachis; (3) A scalariform vessel, its end wall is inclined, there are more scalariform perforations, rachis; (4) Some parenchyma tissue cells, they all are without any perforation in their any walls, rachis; (Pa: parenchyma tissue cells); (5) Some parenchyma tissue cells and fibre elements, all parenchyma tissue cells are without any perforation in their walls, rachis; (Pa: parenchyma tissue cells); (6) A bigger scalariform vessel, its side walls have more perforations, rachis.

results further justified also that perforations of vessel elements are the result of plant development, and these perforations are only formed in vessel elements, not formed in other parenchyma tissue.

In the pinna, several reticular vessel elements, the diameter are $23-25 \mu \mathrm{m}$, they have an inclined wall, and some perforations in the end wall and lateral walls (Figure $8(1)$ ). In the pinna, though they are together with those vessels which possessed perforations, these parenchyma tissue cells have only a primary wall, and have no perforations (Figure 8(3)), indicating that the primary wall is not dissolved to form perforation by enzymes [12]; perforations can be seen only in vessel elements. In the pinna, some scaraliform vessels's 


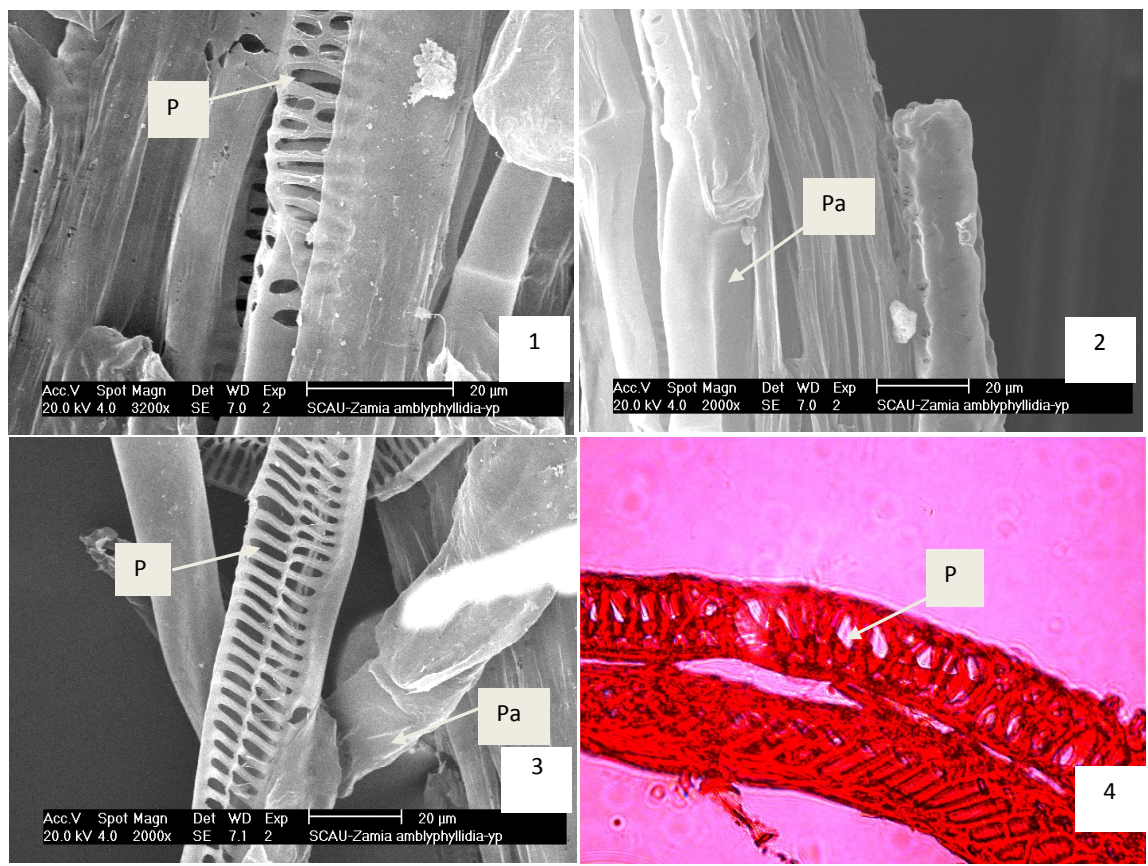

Figure 8. (1) Some reticulate vessel elements, aspect of them, the side walls have perforations, through these perforations, can seen the ornamentation inside of the vessel element, and some lateral walls of other elements still are without perforations, the membrane which is consisted by primary wall in the vessel element surface, through these membranes, can seen the ornamentation which is consisted by secandary wall, pinna; $(P$ : perforation); (2) Some parenchyma tissue cells and accessory transfusion tissue cells, all parenchyma tissue cells are without any perforations in their any walls, pinna; ( $\mathrm{Pa}$ : parenchyma tissue cells); (3) Several scalariform vessel elements, there are some scalariform perforations in the side walls, through these perforations, can seen the ornamentation inside of the vessel element; those parenchyma tissue cells in side of the vessel elements, and are also without any perforations in their any walls, pinna; (P: perforation, $\mathrm{Pa}$ : parenchyma tissue cells); (4) Two scalariform and reticulate vessel elements, the lateral walls of the latter possessed some large perforations, (Under light microscope, light come from in bottom of sample, so the sites of perforations are a lot of light passed through, therefore there are obvious bright), pinna; (P: perforation).

diameters are $23-25 \mu \mathrm{m}$. There are more near long perforations in the side walls (Figure 8(4)).

\subsection{Guaiacum officinale}

In the stem, some spiral vessel elements are little, the diameter is $7.2-8.2 \mu \mathrm{m}$, the lateral walls have some perforations, some perforations are $6.5 \mu \mathrm{m}$ length, and $5.8 \mu \mathrm{m}$ width (Figure 9(1), Figure 9(2); Figure 10(1), Figure 10(3)), the end wall is inclined. Some reticular vessels, the diameter are $12-15 \mu \mathrm{m}$, the side walls have more perforations, a part of perforations are bigger, their diameter is $7 \mu \mathrm{m}$ length with $4.2 \mu \mathrm{m}$ width (Figure 9(3)). On the vessel element side, there are some accessory transfusion tissue cells, their near short rectangle shape and the side walls and horizontal or near horizontal end walls have more perforations (Figure 9(1)). 


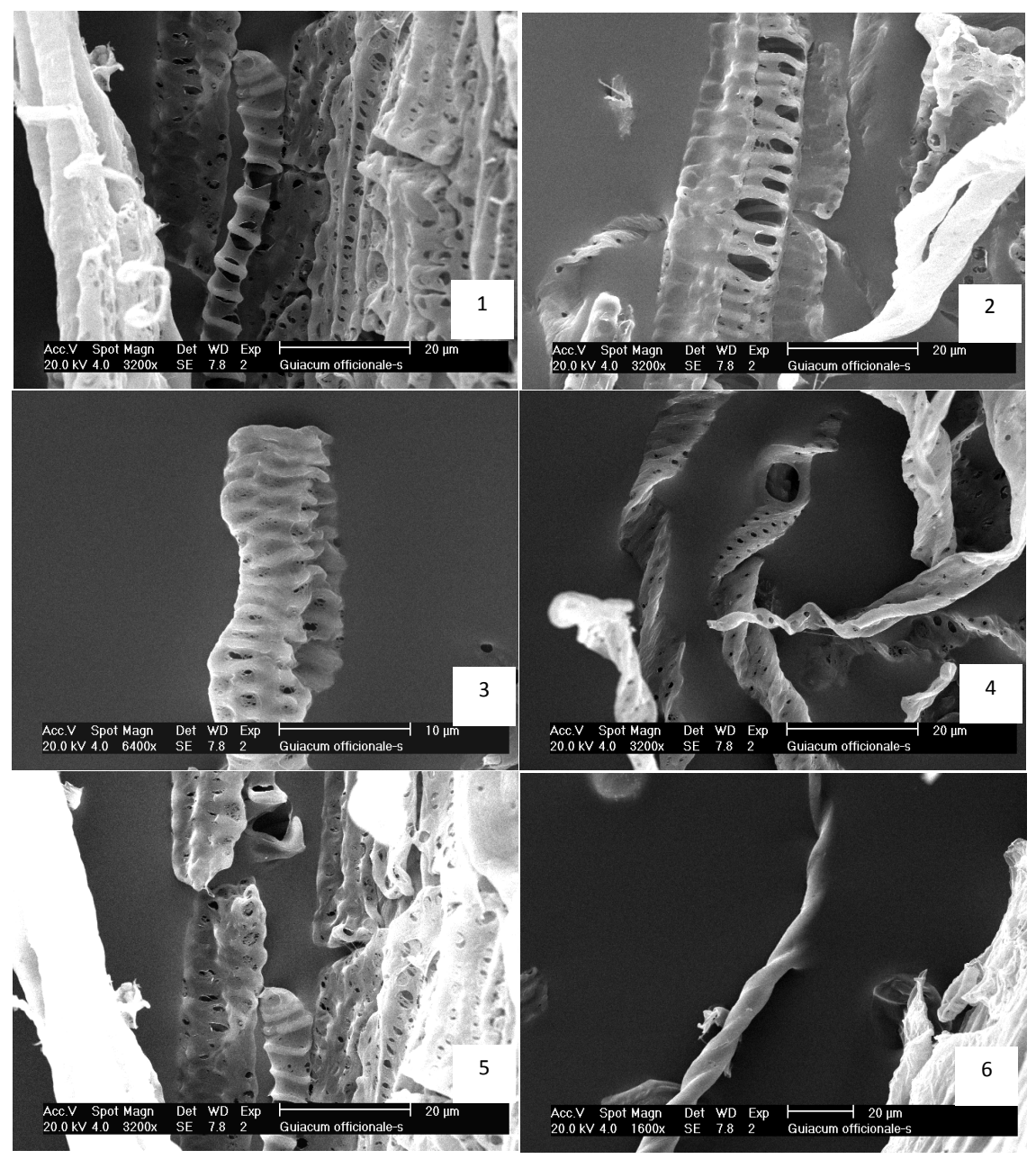

Figure 9. (1) Spiral vessel elements, it's side wall and end wall have more littile perforattions, in the vessel element side, there are some accessory transfusion tissue cells, their near short rectangle shape and the side walls and horizontal or near horizotal end walls have more perforations, stem; (2) Several spiral vessel elements, their side walls have many large perforations, (3) A reticular vessels, it's end wall is horizontal and side wall has more littile peforattions, stem. (4) Several pitted vessels, their end wall are twinst shape, formed a inclined wall and has a tip, in the end wall has a large perforation, stem. (5) Some reticular vessel elements and a spiral vessel, the former' end walls are horizontal or near horizontal, and some perforations in every end wall, formed multiple perforation plate, the lateral walls have also some perforations, stem. (6) The fiber element is thing and longer with a twinst shape, stem.

In the reticular vessels, the diameter is little, only 17 - $18 \mu \mathrm{m}$, their side wall has more littile perforations; some reticular vessels near circular, the end wall are horizontal, in the side walls have some little perforations (Figure 9(5)). In aspect of pitted vessels, their end wall are twist shape, formed an inclined wall and has a tip, in the end, wall has a large perforation, the diameter of about $7.8 \mu \mathrm{m}$, this twist shipe shape is similar to other vessel elements of angiosperms [7] [9], belong to the more primary vessel type (Figure 9(4)).

The fiber element is a thing and longer with a twist shape, the characteristic is same as the fiber of other angiosperms [7] [9] and cycads (Figure 9(6)). In leaf, 


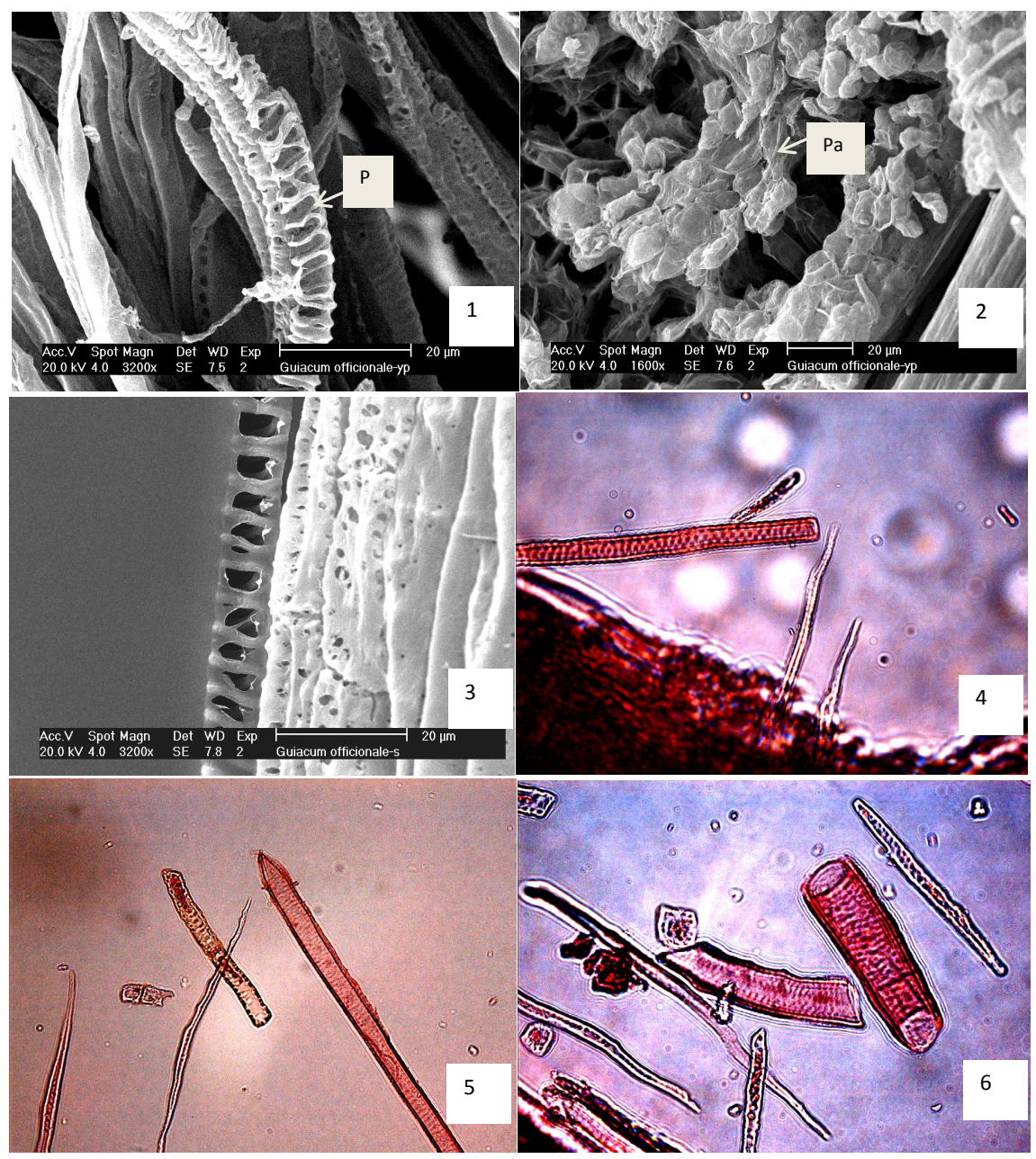

Figure 10. (1) More spiral vessel elements, their side walls have already formed more perforations, leaf; (P: perforation); (2) Some parenchyma cells, they are without any perforations in their cell walls; (Pa: parenchyma tissue cells); (3) A spiral vessel, its lateral wall formed more perforations, in its around, the cell walls of accessory transfusion tissue have also some perforations. (4) A pitted-reticular vessel element, its side wall and end wall have some perforations, its end wall is horizontal shape, stem; (5) Two pitted-reticular vessel elements with two fibre elements, the lateral wall of the vessel elements have many perforations, their end walls are inclined or tip shape, and there are several perforations formed multiple perforation plate, stem; (6) Two large reticular vessel elements, their side wall have many perforations and every end wall is inclined or near horizontal shape with a bigger perforation, it is whole perforation plate dissolved to form a single perforation plate, stem.

the parenchyma cells are without any perforations in their cell walls (Figure $10(2))$.

These spiral vessel, reticular vessel and pitted vessle in the leaf of this species, these vessels are more circular, not similar to and angiosperms and cycads vessels, have several ridges in the different directions of side walls, so that they are as polygons in the cross section.

Like many angiosperm [13] [14], some of pitted-reticular vessels have large perforations in the lateral wall reaching $5.2-6.1 \mu \mathrm{m}$ long, $1.6-2.2 \mu \mathrm{m}$ wide 
(Figure 10(5)). The wall of parenchyma cells is like a thin membrane and is not perforated (Figure 10(2)), indicating that the primary wall are not dissolved to form perforation by enzymes [12]; perforations can be seen only in tracheary elements.

Around the spiral vessel elements, the cell walls of accessory transfusion tissue have also some perforations (Figure 10(3)). In the xylem of angiosperm, the accessory transfusion tissue is together with vessel, and the cell walls have some perforations have been not seen report in past time. These perforations are bountiful to aqueous solution of vessels cross transport entered to these tissues, then transport to leaf and other tissues.

In stem, some pitted-reticular vessel element, its side wall and end wall have some perforations, its end wall is horizontal shape, but some end walls of pitted-reticular vessel elements are inclined or tip shape (Figure 10(4), Figure 10(5)). In some large reticular vessel elements of stem, their side wall have many perforations and every end wall is inclined or near horizontal shape with a bigger perforation, it is whole perforation plate dissolved to form a single perforation plate (Figure 10(6)).

\section{Discussion}

\subsection{Analyse the Characteristics of Vessel}

Seen these vessel elements of cycad species, their end wall have more inclined, few of them are near acuate, and more state are near horizontal shape, their end walls have several large perforations, some have more perforations, these characteristics are same as vessel of more angiosperms, even apart of characteristics are more evolution than that of angiosperms [7] [9]. In each species, the lateral walls of all types vessels have more perforations, and the diameter is large, these are scalariform, near circular and reticular, etc., these characteristics are the same as leaves of angiosperms [7] and stem of angiosperms [9], the function of perforations main is that making xylem vessel element not only can long transport aqueous solution, but also can cross transport the solution between the vessel elements. Thereby, caused xylems can play the largest overall harmonizes transporting action so that the tissues of root, stem and leaf can obtain the water and nutrients as used or stored.

Compare with these species of Cycadaceae and Zamia erosa of Zamiaceae which are distributed in America in those vessel characteristics of evolution or primary, they are not shown that the latter is more evolution than the former. In the former, the general view is that vessel diameter is bigger, the end wall is more horizontal is more evolutionary. Our research showed that more primary species of Cycas of Cycadaceae possessed more evolutionary vessel characteristics than Zamia of Zamiaceae.

The theory of comparative morphology suggests that vessel elements evolved gradually from tracheids whose end (bottom or top) is pointed in the shape of a cone. Therefore, one or two lateral walls gradually change to form near $90^{\circ}$ di- 
rection with interior wall of lateral wall, so the end wall of the more primitive vessels is sloping and possess a clearly and long pointed tail. Conversely, the vessel elements are more evolved and their end walls have gradually become horizontal or near horizontal (end wall formed $90^{\circ}$ angle or near $90^{\circ}$ angle with interior wall of lateral wall) and basically have not a tail, and the characteristics which the diameter of vessel is bigger are more evolutionary [13] [14] [15], and the characteristics which the length of vessel element is longer are more evolutionary, because thus vessel, their number which interconnected points of possessed perforations' end walls is fewer, so that the conduction speed is faster in unit length range [7] [9].

Seen the vessel elements of these different cycads species, the vessel diameter of Cycas armstrongii is larger, specialy the scalariform-pitted vessel, the diameter reached $35-47 \mu \mathrm{m}$, however, other vessel elements diameter of species are 20 - $35 \mu \mathrm{m}$. Among spiral vessel diameter is smaller, scalariform vessel is middle, the diameter of scalariform-reticular vessel is bigger, and most pitted-reticular vessels are biggest. The diameter of some bordered pitted vessels is larger, and simple pitted vessels are smaller. Comparative with Zamia, vessels of Cycas are bigger than the laters, although laters are more evolutionary texon. So these are different from the viewpoint which thought the diameter of vessel of more evolutionary plant texons probobry is bigger than that more primitive texons.

Comparative these cycads with Guaiacum officinale of angiosperm, the elements of the latter are smaler, even if the diameter of the reticular vessels is also only $17-18 \mu \mathrm{m}$, they are less than that of Cycas and Zamia. Therefore, it is not shown the evolutionary characteristic that the diameter of vessel of the more evolutionary plant is bigger. This is consistent with the previous report [7] [9]. In spiral vessel, scalariform vessel and reticular vessel of cycads, they are also more possessed the end wall of near acuate more inclined shapes, some possessed a tail tip. Some end walls of vessel elements are near horizontal, there are perforation and multiple perforations, and many perforations are located in the lateral walls. These characteristics are the same as other angiosperms. Apart of vessels are twisted shape, some are like a flat twist shape, these vessel elements twist together each other, their perforations of lateral walls can docking and communication each other, meanwhile can increase the mechanical support capability. These characteristics of vessel are same as the leaf [7] and stem [9] of angiosperms.

Different to other cycads or angiosperms species, more vessels of leaf and branch of stem of Guaiacum officinale have been not seen the ridges in the different directions of side walls which can make vessel has more mechanical supportability, but some possessed the ridges; however, more vessel elements are twist shape and can twist together each other, thus the state can increase their mechanical supportability, and their synergy with fiber elements which is longer with a twist shape, therefore their capability of xylem conduction and the combine mechanical support capability with mechanical tissue are also stronger. 
Guaiacum officinale is the plant of Zygophyllaceae, it major distributed in tropical region of America, and located in a middle evolutionary position, its vessel elements is similar to more cycads but comparative with the vessel elements of primary family such as Magnoliaceace are evolutionary, comparative with some more evolutionary species of Rosaceae, vessel elements of Guaiacum officinale are more primary [7] [9]. These showed that in respect of plant evolution, it is not that all tissues evolve in same time, only a part of tissues is an evolution or more evolutionary, other tissues are slowly evolving, as long as they can meet their needs to environmental adaptation and growth and development.

Compared to the angiosperms, the perforation plate of every end wall of these vessel elements in Cycadaceae, Zamiaceae are very well developed [7] [9]. They have larger perforations than $G$. officinale even and larger than many angiosperms which are main multiple perforation plates such as the scalariform perforation plate and the reticulate perforation plate [13] [14] [16].

Some multiple perforation plates in the end wall have several perforations that are quite large, for example, the scalariform vessel of Cycas angulata, Cycas armstrongii and Cycas conferta, etc. usually has 6 or 7 perforations and some scalariform or scalariform-pitted vessels have $4-5$ perforations in the perforation plate. In Cycas conferta, the perforation plate has 2 - 3 large perforations, the length is more than $40 \mu \mathrm{m}$, and the width is more than $20 \mu \mathrm{m}$, this index is several times of the indexes of many angiosperms [14] [17] [18]; a few of them possess 2 - 4 perforations in the near horizontal plate; in most of vessel of gymnosperms and angiosperms, their perforations length is $6-12 \mu \mathrm{m}$, the width is 4 - $7 \mu \mathrm{m}$, some length is $15-20 \mu \mathrm{m}$, width is $10-15 \mu \mathrm{m}$. Thus large perforations can pass through quickly all substances in aqueous solution, even if $\mathrm{PM}_{2.5}$, or $\mathrm{PM}_{10}$ of the atmospheric pollutants are also pass through quickly. In the vessel end walls of many species of more primitive angiosperms have dozens or more than 100 or even 200 small perforations [14] [17] [18], Thus, the structures of the vessels of gymnosperms have evolved more, to favor the rapid transport of large amounts water, as well as inorganic and organic nutrients [19].

Compared with the vessels of G. officinale, and vessels of Magnoliaceae, Rosaceae [7] [9], the vessels of this research and other researches of Cycadaceae [2] [4] [7] [8] [9] of this research and Taxodiaceae, and Cupressaceae [9], generally have less inclination in the end wall perforation plate, their end walls are closer to horizontal, and some are horizontal. Michelia alba, M. figo, and Amygdalus persica generally have a long and very oblique end wall perforation plate, and the inclination is so acute, that it is very difficult to distinguish between the end wall and the border of the lateral wall [7] [9]. Thus, these vessels of the gymnosperms indicate a more advanced status for this index. These characters exist also in other cycads and angiosperms [8].

Many vessels of Michelia alba have no top plate in their end section, only an acute or a line-like margin at the end, meaning that they lack an end wall. The end portion only consists of two wider lateral walls that are flat and band-like, 
adjoining elements of vessel connect each other rely on only these perforations which locate in these lateral walls, their end is more acute or point and without perforation [9]. These characters are more or most primitive characters of vessels [7] [20]. Previously, vessel elements were thought to preserve a very oblique top plate, horizontal or close to horizontal; in fact, there are vessel elements that have no end wall or call top plate as if it is very oblique, adjoining vessel elements by connecting at the perforations in several lateral walls. The vessel element concept is like or approaching an individual tube cell which is open at each end [21], or an elongate, open-ended cell [22]; and vessel element every end possess a or several perforations [13]. The tracheid concept is that tapered cells, with overlapping ends and often spiral thickening of cell wall, rather than being open-ended, perforations [22], tracheid is no perforation cells [13]. The character which differentiates vessel elements and tracheid elements is whether it possesses perforations in the end wall. Vessel elements have a perforation in end walls. In fact, many vessel elements like in Michelia alba are without end wall, and only have two lateral walls and a margin, like a flat band, those perforations located in lateral wall approach the end, and can be thought of as the end. Some vessel elements of Guaiacum officinale are also thus characteristics. These vessel elements can then still have a large capacity for conduction, even exceeding that conferred by having only a top plate in the end wall as a result of the several surfaces of the lateral wall and the more numerous or larger perforations. Furthermore, the structure can serve a more important function than a vessel element by connecting two or more vessel elements in a longitudinal direction. In this way, even if these features are more primitive in their structure, they are still preserved in more advanced plants such as angiosperms.

In this research, we observed that leaf and stem of Guaiacum officinale possessed accessory transfusion tissue, in the xylem of angiosperm, the accessory transfusion tissue is together with vessel, and the cell walls have some perforations that have been not seen report in past time.

Some vessel element of Michelia alba, Michelia figo and Amygdalus persica of angiosperms and cycads [7] [9], and the vessel elements of Guaiacum officinale possess a twisting shape, that can enable several adjoining vessel elements to connect together. Thus, such a structure improves conduction and confers greater mechanical support at the same time.

In this study, perforations were seen only in vessel elements, the cell wall of parenchyma cells only had primary walls without any perforations, although these cells of parenchyma were distributed in the around or very close to vessel elements, indicating that enzyme action has specificity for tracheary elements and not dissolve parenchyma cell walls, whereby they can preserve the integrity of the thin membrane-like wall.

Same as the vessel elements of angiosperms and gymnosperms [7] [8] [9], in this research, all species in our research, in these vessels, some sites have perforations and other sites have no perforation in the same vessel element, those sites 
consist of primary wall located in vessel surface. These results showed that perforation formed and differentiated have special site and function.

Furthermore, in some vessel elements, only 2 large perforations are formed in the end wall, such as rachis of Cycas conferta, etc., however, its lateral wall does have not any perforation. Otherwise, our observations have a peculiarity that in any species of plant, there are perforations in all end or end walls, some end walls have no perforation, only lateral walls have perforation, some vessel element of Michelia alba which only has a margin at the end and no end wall. Even if some vessel elements are without any perforation in the lateral wall, their end walls also possess perforations. These results demonstrate that the end walls of vessel elements certainly possess perforations, and the site of perforations formed are selective. These characters showed that forming of perforation is a phenomenon of adapting to the transport function of plant which formed in some especially places of vessel, and it does not form randomly in any tissue or any place.

\subsection{The Measures of Research Vessel Elements}

These characters studied here also demonstrate that the experimental methods are stable and scientific. Furthermore, these characters testify that like very few prior workers [23] who surmised that the pit membranes consist of primary wall which may easily be damaged in procedure using Jeffrey's method (10\% nitric $-10 \%$ Chromic acid, 1:1) are wrong. Because this method has been through many replications and shown to be stable and reliable, it does not damage pit membranes, so, since 1940, this important method, [24] is widely utilized to study vessel element structure including angiosperms, ferns, gymnosperms. Most vessel research uses this method, only a few studies used other methods such as sodium hypochlorite in dissociated solution. These are among the strongest oxidizers, with oxidized intensity higher than Jeffrey's method solution. It should and must be noted, in these solutions of several experimental methods, the solution of Jeffrey' method is most moderate. And that the method procedure requires low than $60^{\circ} \mathrm{C}$, and stops isolation (maceration) then the tissues have to begin separated, this is the safest and stable method [9].

Our research results showed that perforations were seen only in tracheae, the cell wall of parenchyma cells only had primary walls without any perforations in the same vision, it proved enough that Jeffrey's solution may not damage primary walls which are parenchyma cells walls, and the composition of pit membranes. In other words, if Jeffrey's solution may damage primary wall that which shall be damaged all cells wall randomly in any tissue so that tracheary elements and parenchyma cells walls all shall form many perforations. But this is without the situation in previous research [2] [3] [4] [7] [8] [9] and our research.

If who make so-called evidence want to testify that Jeffrey' method is a mistake, that who certainly is not in the light of the procedure of Jeffrey method, he certainly is used a such as overpass $100^{\circ} \mathrm{C}$ situation, and after tissues have sepa- 
rated, he deliberates still continue long term isolation, but, this is not Jeffrey's method, and is a deliberate distort and sabotage action to the method.

In the research of Carlquist and Schneider [23], measured which materials were cut sections 1 - $2 \mathrm{~mm}$ thick by hand, then fixed in aqueous $70 \%$ ethanol, and were air-dried on a warming table, exhibited those figures which tracheary elements have many reticulate or porose pit membranes in ferns because they thought that their earlier studies on fern xylem were based on macerations prepared with Jeffrey's fluid. Macerations of dicotyledonous woods and even of xylem of monocotyledonous roots and stems [25] [26] tend to leave pit membranes in lateral walls of vessel elements intact; they, therefore, assumed that these methods would result in similar results with fern xylem. That assumption proved faulty because fern roots and stems are refractory when treated with Jeffrey's fluid. Successful macerations require prolonged treatment, apparently because the xylem is associated with thick fibrous sheaths. Although secondary wall architecture was not damaged by prolonged maceration, they believe that the integrity of primary walls was lost to various degrees by prolonged oxidative treatment. As such, Carlquist and Schneider [23] believed that revisions in their earlier reports are therefore required. Certainly presence of porous pit membranes, reported in their earlier studies, has been confirmed in this study, although with improved preservation and imaging. However, reports of multiple perforation plates, lateral perforation plates, and intermittent perforations in fern tracheids should be regarded as erroneous; reports of perforation plates lacking any pit membrane remnants in such genera as Microgramma and Vandenboschia [27] may be the result of excessive maceration; even if they thought that in their study to several species of cycad, they observed some characteristics which on the surface of pores or perforations were threadlike, sheet-like, shred-like, mesh-like in shape were the result of peroxide [25], but this is error.

But see to their figures of the research which were treated by macerations [27], their figures of experimental results had a very typical character because of artificially excess treated so that all pits in tracheary tissues were shaped perforations in all cell walls, these specimens are without any pit membrane was integrated. Their study had not the situation that all end walls possessed perforations and only a part of sites of lateral walls have perforations, and some sites were without perforation with there were integrated primary wall (without any reticulate or porose pit membranes). Thereby, their research result maybe was an excess treatment by maceration solution. Otherwise, they did not exhibit the pictures of cells of parenchyma tissues and were without any a picture which was that the cells of parenchyma tissues together with vessel elements, if they so excess treat, should have induced to these cells of parenchyma tissues formed perforation at the same time, but they did not notice this content.

They thought that this measure [23] which is cut sections $1-2 \mathrm{~mm}$ thick by hand, using single-edged razor blades. Then fixed in aqueous $70 \%$ ethanol and air-dried on a warming table was mild, this is not sure. Because they only exhi- 
bited tracheary elements, and were without exhibit cells of parenchyma tissues, the cells of parenchyma tissues possible had possessed porose or reticular wall. Because the materials with ethanol dried in air are not mild, because ethanol volatilizing quickly it easy make material quickly contract and drag, or transmutation. Thereby, almost all scholars use the new measure that dehydrated in a graded series of ethanol and isoamyl acetate and critical point-dried in $\mathrm{CO}_{2}$, because this measure is really mild [9].

Otherwise, their sections from hand used reamer was very easy formed damage to the primary wall that take off the materials of primary wall, those materials of the primary wall shall be stuck in reamer, and be peeled off, then these sections put in $70 \%$ ethanol solution, they formed like uniformity porose or reticular primary wall (pit membrane of tracheary element) at once like their figures [23]. These very deserve oppugn and more exploration. They thought also that artifacts, such as tearing or cracking of pit membranes, are readily recognized as stress-induced phenomena. Pit membranes are "striated" (minutely corrugated) occurred both in their earlier studies and in the study [23] (Figure 3 , upper left) and very likely result from kinds of stress, such as heating by the SEM electron beam. Such stress artifacts are easily recognizable as different from the reticulum of pit membranes that results from natural hydrolysis of the cell wall [23].

But this is ungrounded, because if primary wall can be heated by the SEM electron beam so that formed perforation, the process which is hit form perforation shall certainly be seen, because that is impossible occurred that then tracheary element entered the field of vision of SEM, at once all are heated to artifact perforation in split second, they certainly have a changing process can be watched by observer, in our many pieces of research, we were all without seen the phenomena [7] [8] [9]; Moreover, those materials of plants had been sputter-coated a layer gold membrane in their outside, therefore they were firmly fixed and safeguarded, thereby they complete could not be heated formed perforation by SEM.

Otherwise, it is none proof showed why heating by the SEM electron beam stress only locate in tracheary elements, and they were heated formed perforation in the primary wall (pit membrane), whereas, those walls of parenchyma tissues cells which consist of only primary wall were not heated formed perforation, if SEM electron beam can be heated the cell walls formed perforation, it shall not only are heated to artifact perforation in vessel elements, but also shall cause all cell walls of parenchyma tissue formed perforations, but the facts are not thus, all cell walls of parenchyma cells only had primary walls without any perforations in the same vision with vessel elements. Because our former researches [2] [4] [7] [8] [9] and this research showed that the surface of primary wall in many of tracheary elements of plants where have not perforation formed are same integrity, thickness and smoothness as parenchyma tissues, and there are without any porose or reticulate phenomena. 
Moreover, many treated materials of plant by other methods, are not needed observation by SEM, and are enough only observed by light microscope, this is a condition without any heating by the SEM electron beam stress, those perforations of naturally formed in end walls and some lateral walls can be observed same as in SEM. In light microscope, light ray came from underside, thereby, the sites of perforation are bright, those sites are distinctness differentiate to there are without perforation and possessed integrated primary wall.

They thought also that observed from inside tracheary elements of the several species of cycads there had some spiral secondary thickening, look like pits [28]. But we thought that any secondary wall is formed inside of primary wall of plant tracheary elements, they have spiral, scalariform, pitted and reticular ornamentation, and the primary wall like a membrane, they located in periphery of tracheary elements, then formed perforations, it is the periphery primary walls be dissolved by enzyme, so these perforations are without any relations with those inside ornamentations, and observe the perforation of tracheary element ought to observe the primary wall situation in outside of the tracheary element and are not observe inside of them. In addition, in our former researches, observed from inside of vessel element, many were without seen the spiral thickening phenomenon [7] [8] [9].

Any vessel element is all need to pass through the individual development process that it from the shape which is without any wall perforation, to the shape which wall (pit membrane) have retained thread-like, sheet-like, shred-like or mesh-like membrane remnants of the primary wall in the periphery of the perforations. With some not complete perforations, these remnants are evidence that the primary wall gradually developed small or more than a half perforations, and eventually these wall remnants completely disappeared, leaving large, entire perforations [13] [15] [16]. As these perforations differentiated, the dissolving membrane remnants were reabsorbed by the plant, until the membranes completely disappeared, then developed to the shape that possessed some or many complete perforations. This is a vessel individual development phenomenon; these characteristics exist in this research, these results justified also that this is an individual development process. These are not like the formers [23] [28] said that then used the method which is cut section by hand, should can see only that all vessel elements are the situation which all perforations are incomplete with some web, silk, filiform, etc membrane remnants in surface; and are not as former said that they are only the characteristics of systematics development [23] [28].

Therefore, they [23] [28] take very little partial sites pictures which immature tracheae element wall only have web, silk, filiform remnants and not expressed the characteristics of other sites where we're have developed mature vessel elements, therefore said that this is a systematics development phenomena, and said that this species is without complete perforation, it is at the status which tracheid prepare to develop forward vessel. This is also subjective and error. 
Thereby, we thought that their hereinbefore parlances have many errors, and are a subjective guesswork.

In our former research [9], we used the method as the literature [23] [28], it is without any dissociated fluid, see the structural characteristics of rachis of Cycas szechuanensis (Figures 4(A)-(D)), all longitudinal section and cross section were the situation that perforations exist in tracheary elements and without perforations in parenchyma cells, especially the cross section (Figure 4(D)), can observed some larger perforations located in end walls and lateral walls inside vessel pipe hole; in these places, where are without go through any dissociated situation, and are without any touch by tool in the process of sectioning by hand, therefore, these perforations are most pure natural situation; these structural characteristics are same as the method that used the isolation process of Jeffrey's. These results also further adequately proved that Jeffrey's method are scientific and reliable.

In this research, seen the cross section of rachis of Cycas szechuanensis (Figure 4(D)), can observe some larger perforations in end walls and lateral walls through the pipe hole of vessels; in these places, where are without going through any dissociated situation, and are without any touch by tool in the process of sectioning by hand, therefore, these perforations are most pure natural situation; these structural characteristics are same as the method that used the isolation process of Jeffrey's. These results also further adequately proved that Jeffrey's method is scientific and reliable.

On the question, some scholars have already made a specialized comparative experimental study [29], They to the secondary xylem from five woody species used as following four methods made experiment, include the fresh materials were cut sections $1-2 \mathrm{~mm}$ thick by hand [23], in low vacuum and then the same materials were air-dried and examined both in low- and high-vacuum with SEM and the materials were treated by Jeffrey's Fluid and observed in high-vacuum with SEM. The results showed that the pit membrane in the pits and the remnants in the perforation and the structural characteristics of perforations were not notably different from that in different processing and handling as well as in low- and high-vacuum. The description of the pit membrane and its remnant and perforation based on the SEM observation is validly claimed.

Otherwise, other scholars carried out comparative studies used the paraffin section method with Jeffrey's method, for avoiding the treatment of isolation solution, researched the structure of vessel elements about more than 10 families plants, the result showed that those vessel element same as which were treated by Jeffrey's fluid, the results showed that there were many perforations in the end walls and lateral walls of vessel, and their size was larger and have many completed perforations [30]; these reports were not like the situation which said by Carlquist and Schneider [23] that only could observe the pit membrane-like web, silk, filiform, etc. shape in the perforation surface. These results are all proved that Carlquist and Schneider' [23] report have errors, they only observed the 
very little partial place in wall of vessel element, or only chose the characters which some pits or perforation possessed like web, silk and filiform etc. shape membrane remnants in the surface to made pictures and described, therefore, other places which possessed whole perforations in the wall of vessel, they not observed and not described [9]. So, the first, although their so-call new measure is simple and crude, it was also could basically be used, but the effect is lower than other measures; the second, their reports in several papers which were without any whole vessel element or more proportion of a vessel element can be viewed to the all vessel element' or more places and perforations by reader, only were some very partial sites which have only one or several pits [9]. So these measures and thought [23] [28] are more subjective, on-sidedness and mistake.

\section{Analyse the Evolutionary Extent of Vessel Element of the Two Families}

Cycadopsida have 3 families, the most primary family is Cycadaceae, Stangeriaceae is medium position and Zamiaceae is most evolutionary [31] [32] [33], Cycadaceae distributed in Asia, Africa and Australia etc. countries of Oceania, Stangeriaceae distributed in Africa, Australia, Zamiaceae distributed in Africa, America and Australia, although they distributed so far apart from each other, but they are a well and unified taxonomy system, seen these families, Africa and Australia are the regions which possessed 3 families: Cyacdaceae and Stangeriaceae and Zamiaceae, Australia possessed 1 genus of Stangeriaceae: Bowenia, and 2 genera of Zamiaceae: Lepidozamia and Macrozamia, we thought that because Cycadopsida originated from East Asia [31], so, Australia' most species or all species of Cycadaceae came from Asia, and it is impossible from Africa, because the latter only has one more evolutionary species and lack of fossil of Cycadaceae [31], of course these species of Cycadaceae are the descendants of ancestor species. America possessed more genera of Zamiaceae, this family is mutual with Africa and Australia, we thought that these genera of Zamiaceae in Australia and America came from Pangea before continental drift in Jurassic Period; this family is also maybe one of proofs to Australia drift from Pangea to present position after Jurassic Period.

Zamia erosa is the species of Zamia, it was introduced from America, seen these cycads of the research, the species which possess the most primary characteristics is $C$. armstrongii, its more proportion of end walls of vessel are inclined to shape, and the degree of inclination is bigger. But the characteristics of vessel of $C$. angulata and $C$. conferta evolution are more revolutionary, showed the characteristics that the degree of inclination of more end walls of vessels are smaller, and more end walls of vessel are horizontal or near horizontal; Zamia erosa is one of species of the most evolutionary family in Cycadopsida, although it is more evolutionary in the characteristics of vessel than some angiosperms [7] [9], compared with the 3 species of Cyacdaceae, the evolution degree is a slightly higher than $C$. armstrongii, but lower than that of $C$. angulata and $C$. conferta. 
These showed also that more primary species or taxon, their more tissue characteristics are not also more primary, because of the need to adapt the environment, and they are also constantly evolving.

\section{Conclusions}

1) In this leaflet and rachis of cycads and leaf and stem of Guaiacum officinale, there are annular vessels, spiral vessels, scalariform vessels, reticular vessels, pitted vessels and scalariform-pitted vessels in their conduction tissues. In the transverse section, the vessel elements of Cycadaceae and Zamiaceae are circular, polygonous, more similar to vessel characteristics of petiole and stem of some angiosperms; however, the number of circular vessel of Guaiacum officinale were more.

2) The length of vessel element of Cycadaceae with Zamiaceae are not obvious difference, the length of vessel element of angiosperm Guaiacum officinale is shorter, but their diameter is smaller, we thought that the characteristics which the length of vessel element is longer and the diameter is bigger are more evolutionary, because thus vessel, their number which interconnected points of possessed perforations' end walls of vessel element is fewer, and the passageway space is larger so that the conduction speed and quantity are faster and more in unit length range and unit time.

3) The diameter of vessel is that annular vessel, spiral vessel is least, scalariform vessel is medium, reticular vessel and pitted vessel are the biggest, the characteristic is the same as angiosperm. The scale of diameter of Cycas vessel element is similar to that of Zamia, but the diameter of more vessel elements of Cycas angulata and Cycas conferta are bigger than the latter, and is bigger than that of Guaiacum officinale, although Cycas plants are more primitive than Zamia plants, and Guaiacum officinale is more evolutionary, but the scale of vessel diameter of Cycas plants is similar to Zamia or bigger than the latter, even larger than Guaiacum officinale, these showed that cycads have evolutionary and more developed characteristics in aqueous solution transport system.

4) Like cycads, in Guaiacum officinale, around the vessel elements, there are accessory transfusion tissues; their cell walls have also some perforations.

5) Different to other cycads or angiosperms species, more vessels of leaf and brach of stem of Guaiacum officinale have not seen the ridges in the different directions of side walls which can make vessel has more mechanical supportability, but some possessed the ridges; however, more vessel elements are twist shape, and can twist together each other, thus the state can increase their mechanical supportability, and their synergy with fiber elements which is longer with a twist shape, therefore their capability of xylem conduction and the combine mechanical support capability with mechanical tissue are also stronger.

6) Combined the comparative studies on research methods that have been made by some scholars made discussed and analysed with our research showed that any parenchyma tissue cells are without perforation, all cell walls are smoothed 
and like a membrane, justified Jeffrey's method is very reliable and reasonable; only vessel element can form perforation, and in other, all parenchyma tissue cells cannot form perforation are also proved that the perforations of vessel element are natural inherited character.

7) Although they are distributed so far apart from each other, they are a rather well and unified taxonomy system, Australia' most species or all species of $\mathrm{Cy}$ cadaceae came from Asia, and it is impossible from Africa, because the latter only has one more evolutionary species and lack of fossil of Cycadaceae, these species of Cycadaceae are the descendants of ancestor species; America possessed more genera of Zamiaceae, this family is mutual with Africa and Australia, we thought that these genera of Zamiaceae in Australia and America came from Pangea before continental drift in Jurassic Period, this family is also maybe one of the proofs to Australia drifted from Pangea to present position after Jurassic Period.

8) The characteristics of tracheary element of several different genera of cycads and the angiosperm further showed that more primary species or taxon, their tissue characteristics are not also more primary, because of the need to adapt to the environment, they are also constantly evolving.

\section{Acknowledgements}

This project reaches was supported by George Brown Darwin Botanic Gardens, Australia; Research Institute for Environment \& Livelihoods, Charles Darwin University, Australia and Open Lab. of Biology in CDU, Australian National University. The authors thank The Museum and Art Gallery of the Northern Territory, Australia and the vice president of the Cycad Society of China, Professor Nian Liu for support.

\section{Conflicts of Interest}

The authors declare no conflicts of interest regarding the publication of this paper.

\section{References}

[1] Hu, Y.F. (1995) Discoveries of Some Reproductive Organ of Fossils of Cycads in China and on the Origin of Cycads. Chinese Bulletin of Botany, 12, 43-48.

[2] Huang, Y.Y. and Zhang, H.D. (1999) The Brief Report on Discovery of Vessel in Cycads. Journal of Guangxi Agricultural and Biological Science, 18, 161-162.

[3] Lin, J.Z. and Huang, Y. (1999) Discovered Vessel in Cycads Again. Journal of Guangxi Agricultural and Biological Science, 18, 332-335.

[4] Huang, Y.Y. and Wei, L.J. (2004) Discovered Vessel in the Plant of Stangeriaceae of Cycadopsida. Journal of Guangxi Agricultural and Biological Science, 23, 86.

[5] Huang, Y.Y. and Liao, W.B. (2004) Primary Report on Discovering Vessel in Plants of Coniferae and Taxinae. Acta Scientiarum Naturalium Universitatis Sunyatseni, 43, $125-128$.

[6] Huang, R. and Wu, J. (2007) Vessels Discovered in Cycas panzhihuaensis L. Zhou et S. Y. Yang. Journal of Sichuan University (Natural Science Edition), 44, 430-433. 
[7] Huang, Y.Y., Liao, W.B., Zhang, H.D., Wang, J.Z. and Wu, Y.H. (2008) Comparative Studies on Structural Feature of Vessels of Four Genera of Cycads with Angiosperm. Acta Scientiarum Naturlium Universitatis Sunyatseni, 47, 77-86.

[8] Huang, Y.Y., Liao, W.B., Zhong, X.Q., Wei, L.J., Zhang, H.D. and Lu, Y.F. (2010) Structural Characteristics of Vessels in Three Families of Cycadopsida. Journal of Life Sciences, 4, 1-15.

[9] Huang, Y.Y., Han, Y.H., Wei, L.J. and Wang, J.Z. (2017) Comparative Studies of Tracheary Element Structure of Some Gymnosperms with Angiosperms. American Journal of Plant Sciences, 8, 959-984. https://doi.org/10.4236/ajps.2017.85064

[10] Li, Z.L. (1987) Technique of Plant Microscopic Mount. Second Edition, Science Press, Beijing.

[11] Zheng, G.C. and Gu, Z.P. (1993) Biomicrological Technique. Second Edition, Higher Education Press, Beijing.

[12] Aspeborg, H., Schrader, J., Coutinho, P.M., Stam, M., Kallas, Å., Djerbi, S., Nilsson, P., Denman, S., Amini, B., Sterky, F., Master, E., Sandberg, G., Mellerowicz, E., Sundberg, B., Henrissat, B. and Teerl, T.T. (2005) Carbohydrate-Active Enzymes Involved in the Secondary Cell Wall Biogenesis in Hybrid Aspen. Plant Physiology, 137, 983-997. https://doi.org/10.1104/pp.104.055087

[13] Esau, K. (1977) Anatomy of Seed Plants. Second Edition, John Wiley \& Sons, New York.

[14] Gu, A.G., Lu, J.M. and Wang, L.J. (1993) Evolutional Morphology of Vascular Plants. Jilin Science Technology Press, Changchun.

[15] Li, Y.H. (1986) Botany. Second Edition, Higher Education Press, Beijing.

[16] Sperry, J.S. (2003) Evolution of Water Transport and Xylem Structure. International Journal of Plant Sciences, 164, S115-S127. https://doi.org/10.1086/368398

[17] Carlquist, S. and Schneider, E.K. (2004) Perforation Plate Pit Membrane Remnants and Other Vessel Details of Clethraceae: Primitive Features in Wood of Ericales. International Journal of Plant Sciences, 165, 369-375.

https://doi.org/10.1086/382809

[18] Schulte, P.J. (1999) Water Flow through a 20-Pore Perforation Plate in Vessels of Liquidambar styraciflua. Journal of Experimental Botany, 50, 1179-1187. https://doi.org/10.1093/jxb/50.336.1179

[19] Oda, A., Sakuta, C., Masuda, S., Mizoguchi, T., Kamada, H. and Satoh, S. (2003) Possible Involvement of Leaf Gibberellins in the Clock-Controlled Expression of XSP30, a Gene Encoding a Xylem Sap Lectin, in Cucumber Roots. Plant Physiology, 133, 1779-1790. https://doi.org/10.1104/pp.103.030742

[20] Shao, X.W., Zhu, X., Zhou, Y.L. and Li, Y.L. (2008) Study on Tracheary Elements in 5 Pieces of Ferns. Journal of Beijing Normal University (Natural Science), 44, 615-619.

[21] Stern, K.R., Jansky, S. and Bidlack, J.E. (2003) Introductory Plant Biology. Ninth Edition, The McGraw-Hill Companies, Inc., New York.

[22] Lack, A.J. and Evans, D.E. (2001) Instant Notes in Plant Biology. BIOS Scientific Publishers Limited, Oxford. https://doi.org/10.1201/9780429258312

[23] Carlquist, S. and Schneider, E.L. (2007) Tracheary Elements in Ferns: New Techniques, Observations, and Concepts. American Fern Journal, 97, 199-211. https://doi.org/10.1640/0002-8444(2007)97[199:TEIFNT]2.0.CO;2

[24] Johansen, D. (1940) Plant Microtechnique. Clarendon Press, Oxford.

[25] Carlquist, S. and Schneider, E.L. (1998) Origin and Nature of Vessels in Monocoty- 
ledons. 5. Araceae Subfamily Colocasioideae. Botanical Journal of the Linnean Society, 128, 71-86. https://doi.org/10.1111/j.1095-8339.1998.tb02107.x

[26] Schneider, E.L. and Carlquist, S. (1998) Origin and Nature of Vessels in Monocotyledons. 4. Araceae Subfamily Philodendroideae. The Journal of the Torrey Botanical Society, 125, 253-260. https://doi.org/10.2307/2997239

[27] Carlquist, S. and Schneider, E.L. (2001) Vessels in Ferns: Structural, Ecological, and Evolutionary Significance. American Journal of Botany, 88, 1-13. https://doi.org/10.2307/2657121

[28] Schneider, E.L., Carlquist, S. and Chemnick, J.G. (2007) Scanning Electron Microscope Studies of Cycad Tracheids. South African Journal of Botany, 73, 512-517. https://doi.org/10.1016/j.sajb.2007.04.060

[29] Li, H.F. and Re, Y. (2010) Effect on Pit Membrane and Its Remnant by Processing and Handling in SEM Observations. Abstracts of 9 th National Symposium on Plant Structural and Reproductive Biology, Xi'an, 130.

[30] Yan, X.L. (2007) Systematic Position of Cercidiphyllaceae Based on Morphological Data. Dissertation for Master Degree, Shaanxi Normal University, Xi'an.

[31] Huang, Y.Y. (2001) Studies on Systematics and Evolution of Cycadaceae in China. China Meteorological Press, Beijing.

[32] Walters, T. and Osborne, R. (2004) Cycad Classification: Concept and Recommendations. CABL Publishing, Wallingford. https://doi.org/10.1079/9780851997414.0000

[33] Hill, K. and Osborme, R. (2001) Cycads of Australia. Kangaroo Press, Nashville. 